\title{
Physiological, cellular and molecular aspects of the desiccation tolerance in Anadenanthera colubrina seeds during germination
}

\author{
L. E. Castro ${ }^{a *}$, C. C. Guimarães ${ }^{b}$ and J. M. R. Faria \\ anstituto de Biociências, Universidade Estadual Paulista “Júlio de Mesquita Filho" - UNESP, Avenida 24-A, 1515, \\ Bairro Bela Vista, CEP 13506-900, Rio Claro, SP, Brazil \\ ${ }^{b}$ Department of Agriculture, Universidade Federal de Lavras - UFLA, CP 3037, CEP 37200-000, Lavras, MG, Brazil \\ 'Laboratory of Tree Seeds, Department of Forest Sciences, Universidade Federal de Lavras - UFLA, CP 3037 , \\ CEP 37200-000, Lavras, MG, Brazil \\ *e-mail: lorenaegidio@gmail.com
}

Received: January 11, 2016 - Accepted: June 1, 2016 - Distributed: November 31, 2017

(With 5 figures)

\begin{abstract}
During germination, orthodox seeds become gradually intolerant to desiccation, and for this reason, they are a good model for recalcitrance studies. In the present work, physiological, biochemical, and ultrastructural aspects of the desiccation tolerance were characterized during the germination process of Anadenanthera colubrina seeds. The seeds were imbibed during zero (control), 2, 8, 12 (no germinated seeds), and 18 hours (germinated seeds with $1 \mathrm{~mm}$ protruded radicle); then they were dried for 72 hours, rehydrated and evaluated for survivorship. Along the imbibition, cytometric and ultrastructural analysis were performed, besides the extraction of the heat-stable proteins. Posteriorly to imbibition and drying, the evaluation of ultrastructural damages was performed. Desiccation tolerance was fully lost after root protrusion. There was no increase in 4C DNA content after the loss of desiccation tolerance. Ultrastructural characteristics of cells from $1 \mathrm{~mm}$ roots resembled those found in the recalcitrant seeds, in both hydrated and dehydrated states. The loss of desiccation tolerance coincided with the reduction of heat-stable proteins.
\end{abstract}

Keywords: desiccation tolerance, forest seeds, drying.

\section{Aspectos fisiológicos, celulares e moleculares da tolerância à dessecação em sementes de Anadenanthera colubrina durante a germinação}

\begin{abstract}
Resumo
Durante a germinação, sementes ortodoxas tornam-se gradualmente intolerantes à dessecação, e por isso podem ser utilizadas como modelo para o estudo da recalcitrância. No presente trabalho realizou-se uma caracterização dos aspectos fisiológicos, bioquímicos e ultraestruturais da perda da tolerância à dessecação de sementes de Anadenanthera colubrina em processo germinativo. Para isso as sementes foram embebidas durante 0 (controle), 2,8,12 e aproximadamente 18 horas (sementes germinadas com $1 \mathrm{~mm}$ de radícula), secas por 72 horas, reidratadas e a sobrevivência avaliada. Ao longo da embebição foram realizadas análises citométricas, ultraestruturais e extração de proteínas resistentes ao calor e após embebição e secagem foram avaliados danos ultraestruturais. A tolerância à dessecação foi totalmente perdida após a protrusão radicular. Não houve aumento do conteúdo de DNA 4C quando a tolerância à dessecação foi perdida. Características ultraestruturais de células de radículas de $1 \mathrm{~mm}$ assemelharam-se às encontradas em sementes recalcitrantes tanto no estado hidratado quanto desidratado. A perda da tolerância à dessecação coincidiu com a redução do conteúdo de proteínas resistentes ao calor.
\end{abstract}

Palavras-chave: tolerância à dessecação, sementes floretais, secagem.

\section{Introduction}

Water is essential for life, however, some structures, such as seeds, are known for their ability to tolerate dehydration to a low moisture content and retake metabolism after rehydration (Alpert, 2006). These seeds are called orthodox seeds and desiccation is a stage of their development. Orthodox seeds can be stored for extended periods from

months to years, which facilitates ex-situ conservation of these species. Despite this, some plant species do not produce orthodox seeds, but recalcitrant seeds, which are dispersed through large amounts of water, they lose viability when dried, and therefore can't be stored for long periods (Berjak and Pammenter, 2008). The storage 
limitation for recalcitrant seeds is a problem for ex-situ conservation and for the research about the metabolism of this kind of seed.

Considering the difficulty of ex-situ conservation and the variable degrees of sensitivity to desiccation presented by most species from tropical forest, many studies have attempted to understand what mechanisms provide desiccation tolerance in orthodox seeds that are absent in recalcitrant seeds (Dickie and Pritchard, 2002). Among the known mechanisms, desiccation tolerance is associated with the presence of protective molecules during dehydration, such as heat stable proteins (HSPs) and chaperones, to assist in the assembly or maintenance of the molecular structures during dehydration, preventing their erroneous interactions (Hand et al., 2011).

The capacity to tolerate desiccation has being associated with nuclear DNA content. Orthodox seeds are dispersed in the course of the G1 stage of the cell cycle (2C DNA content), and during the germination process, the mitotic activity is resumed with the duplication of the genetic material (4C DNA content) and cell division (Vázquez-Ramos and Sánchez, 2003). Cells with duplicated DNA (at the G2 stage of the cell cycle) are more prone to stress than cells with $2 \mathrm{C}$ DNA content; hence, these cells have a lower tolerance to desiccation (Faria et al., 2005). Another important aspect associated with desiccation tolerance is the maintenance of integrity of cell structures. Species intolerant to desiccation are not able to ensure the integrity of membrane and organelles (Berjak and Pammenter, 2000).

During germination, orthodox seeds become increasingly sensitive to desiccation, reaching the maximum sensitivity after radicle protrusion (Bewley and Black, 1994). According to Sun (1999), physiological, cellular and molecular mechanisms occurring along the loss of desiccation tolerance in germinated orthodox seeds, could be similar to those responsible for sensitivity to desiccation in recalcitrant seeds, so many studies were basing in orthodox seeds as a model to achieve a greater understanding of sensitivity to desiccation.

In the present study, we used orthodox seeds of Anadenanthera colubrina species to understand the processes that occur during the loss of desiccation tolerance in germination. The species Anadenanthera colubrina (Vell.) Brenan, which belongs to the Fabaceae family, Mimosoideae subfamily, is a deciduous tree, pioneer and occurs naturally from the northeastern states to southern Brazil (Lorenzi, 2000). This species has great ecological importance because it grows quickly and is tolerant to sandy and shallow soils, allowing its use for reforestation in degraded areas and restoration of riparian forests (Carvalho, 1994).

Seeking a better understanding of tolerance and sensitivity to desiccation, the aim of this study was to characterize physiological, ultrastructural, and molecular changes associated with the loss of desiccation tolerance during germination of orthodox seeds of Anadenanthera colubrina.

\section{Material and Methods}

\subsection{Vegetal material and Imbibition Curve}

Fruits of A. colubrina were collected at the Campus of Lavras Federal University during the fruiting season. The imbibition curve was conducted under constant light and temperature of $30{ }^{\circ} \mathrm{C}$ using paper as the substrate. We performed 40 repetitions for 40 individual seeds, which were weighted hour by hour during the first 5 hours, every 2 hours, from the 5 th to the 12 th hour of imbibition, following regular intervals until the characterization of stage III of the germination process.

\subsection{Characterization of the desiccation tolerance loss}

After the characterization of the imbibition curve, we selected 4 different stages along the germination processes: 2 hours, 8 hours, and 12 hours of imbibition, and after radicle protrusion (with $1 \mathrm{~mm}$ radicle length). In each selected stage the water content was determined by humidity test. Then, the seeds were placed upon an aluminum grille inside containers with silica gel at the bottom and kept at $20{ }^{\circ} \mathrm{C}$ and relative humidity (RH) of $20 \%$. The loss of water was monitored using successive weighing, and after weight stabilization, the seeds were kept in the drying environment for 72 hours.

Later, the seeds were pre-humidified and rehydrated at germination conditions. The survival was evaluated by the percentage of normal seedling formation. The pre-humidification was performed to avoid damages caused by the fast entering of water, due to the difference in hydrous potential. During this phase, the seeds were kept in humid environments by 25 hours $\left(100 \% \mathrm{RH}, 30^{\circ} \mathrm{C}\right)$. In the drying and rehydrating assays, 4 repetitions were performed for 25 seeds.

\subsection{Quantifying nuclear DNA}

The $2 \mathrm{C}$ and $4 \mathrm{C}$ DNA content were quantified in dried seeds (before germination) and at the end of germination (with $1 \mathrm{~mm}$ radicle length). Samples of 5 repetitions of individual seed were placed in Petri dishes containing $1 \mathrm{ml}$ of cold buffer solution LB01 to release the nuclei. The nuclei were stained adding $25 \mu \mathrm{L}$ of $1 \mathrm{mg} / \mathrm{L}$ propidium iodide solution. The material was analyzed immediately after the preparation. A total 10 thousand nuclei were evaluated for each sample, employing logarithm scale. The analysis was performed in cytometer Facscalibur (Becton Dickinson), the histograms were obtained using the Cell Quest software, and the statistical analysis was performed in the WinMDI ${ }^{\circledR} 2.8$ software.

\subsection{Analysis of the electrophoretic patterns of the Heat stable proteins}

The extraction of heat stable proteins was performed with dry seeds (before germination) after radicle protrusion (seeds with a radicle length of $1 \mathrm{~mm}$ ). Four points of imbibition curve were selected: $2,4,8$, and 12 hours of imbibition. Four repetitions were carried out for 25 embryo axis of A. colubrine (about $100 \mathrm{mg}$ ) from each point of interest. Total protein content was extracted, and the heat-stable 
protein fraction was obtained according to Blackman et al. (1991). After the extraction, samples of heat-stable proteins were evaluated by electrophoresis in polyacrylamide gel SDS-PAGE $12.5 \%$ (separating gel) and 6\% (concentrating gel), stained with Coomassie Blue solution $0.05 \%$ and decolorizing citric acid solution. The gel was placed on transilluminator to evaluate the intensity of the bands and proceed the photographic record.

\subsection{Ultrastructure}

Transmission and scanning electronic microscopy were applied for evaluating the desiccation damage, following the method proposed by Alves (2004). The evaluations were carried out at the beginning of the germination process, after 2 hours of imbibition followed by dehydration, and at the end of the germination process ( $1 \mathrm{~mm}$ radicle length) before and after dehydration. The material was assembled in aluminum stubs, covered with gold and observed in electronic scanning microscope LEO EVO 40 XVP. We performed 5 repetitions for each individual seed.

\subsection{Data analysis}

In all experiments, it was employed the completely randomized design. The data were tested for normality by Shapiro-Wilk test. Qualitative data averages were compared using the Scott-Knott test at 5\% probability. Quantitative data was analyzed by regression or correlation. The average test was performed using the Sisvar 5.3 software, and the others analysis were performed using the Sigma Plot 12 software.

\section{Results}

\subsection{Imbibition Curve and desiccation tolerance loss}

The recently collected seeds presented moisture content of $10 \%$, and the hydration pattern of $A$. colubrina seeds is presented in Figure 1. The germination was characterized by fast water absorption, and the radicle protrusion occurred in less than $24 \mathrm{~h}$, when the stage III of the germination process was achieved, without presenting a clear stage II.

Figure 1 also presented the survivorship data (normal seedling formation) of $A$. colubrina after 2, 8, 12 and 18 hours of imbibition followed by $72 \mathrm{~h}$ dehydration. The percentage of normal seedling formation presented a negative correlation with imbibition time $(r=-0.985)$, therefore, the increase in imbibition time was followed by a reduction in the normal seedling formation after dehydration and rehydration.

\subsection{DNA content assessment}

Figure 2A showed cytometry pattern from radicle cells before germination (dry seeds) and the Figure 2B showed cytometry pattern after radicle protrusion $(1 \mathrm{~mm}$ root length).

Both cells from radicle tip not imbibed (control) and after protrusion presented nuclei with $2 \mathrm{C}, 4 \mathrm{C}, 8 \mathrm{C}$ and 16 C DNA content (Figure 2). During the imbibition a higher percentage of $2 \mathrm{C}$ nuclei was observed, followed by $4 \mathrm{C}, 8 \mathrm{C}$, and $16 \mathrm{C}$ (Figure 3 ).

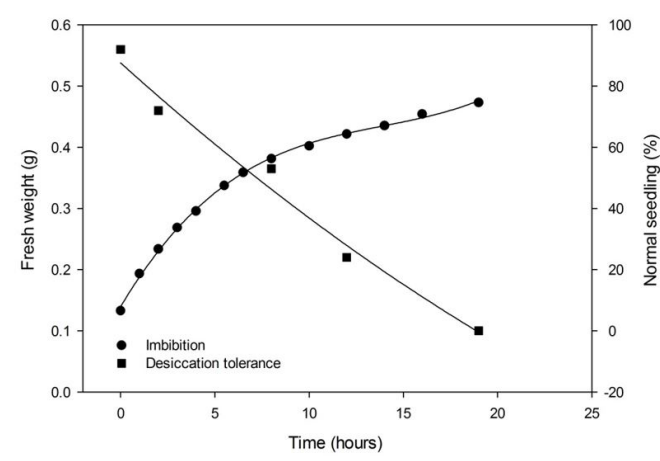

Figure 1. Seed hydration pattern and desiccation tolerance loss (expressed in percentage of normal seedling formation) of Anadenanthera colubrina seeds. Note: To evaluate the desiccation tolerance loss, seeds were imbibed for 2, 8, 12 and 18 hours and dehydrated by 72 hours. $\mathrm{Y}_{\text {desiccation }}=87.5752-5.5465 \mathrm{x}+0.0480 \mathrm{x}^{2} \mathrm{R}^{2}=0.9867$.
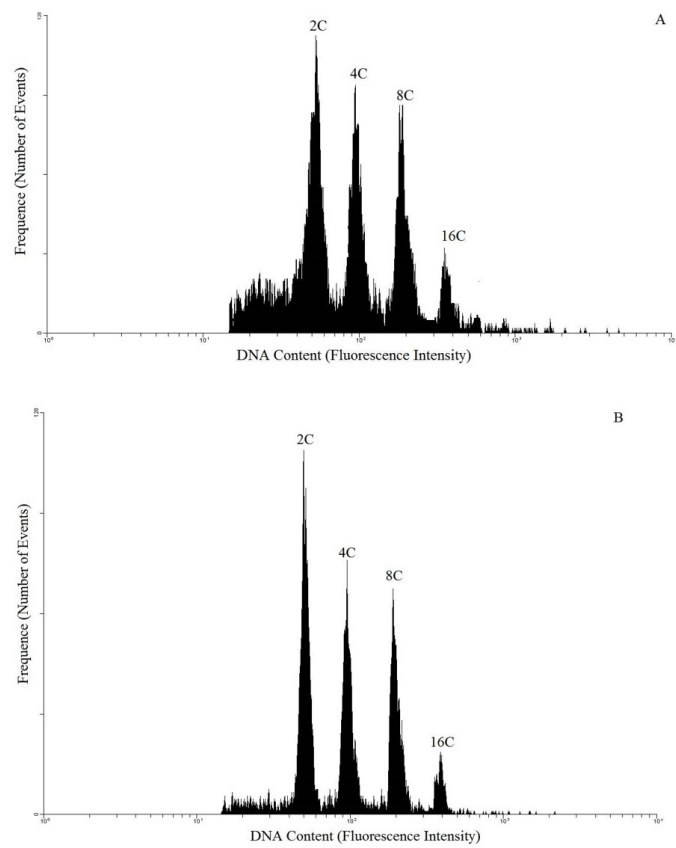

Figure 2. Flow cytometry histograms showing the nucleus DNA content in radicles of Anadenanthera colubrina seeds before (A) and after (B) germination. Note: (A): fresh seeds; (B): $1 \mathrm{~mm}$ length radicles.

Excepting the $16 \mathrm{C}$ percentage, which stays constant, the other percentages were reduced during germination. The number of observed nuclei on S stage was huge, reaching nearly $50 \%$ in dried radicle tips.

\subsection{Heat-stable proteins}

In Figure 4, the electrophoretic pattern of heat-stable protein during germination of $A$. colubrina seeds is showed.

Five main fractions of distinct molecular weight stand out in gel: corresponding to 100,70 and $80,60,50$ and $45 \mathrm{kDa}$, 


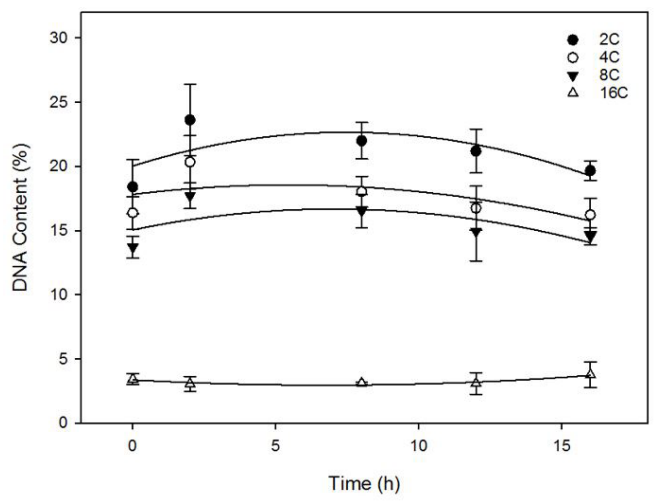

Figure 3. Variation in nucleus DNA content in radicles of embryo axis of Anadenanthera colubrina in different times of germination. $\mathrm{Y}_{2 \mathrm{C}}=22.0365+1.0729 \mathrm{x}--0.1671 \mathrm{x}^{2}+$ $0.0060 \mathrm{x}^{3} \mathrm{R}^{2}=0.9987 \mathrm{Y}_{4 \mathrm{C}}=19.3248+0.3605 \mathrm{x}--0.0847 \mathrm{x}^{2}+$ $0.0037 \mathrm{x}^{3} \mathrm{R}^{2}=0.7959 \mathrm{Y}_{8 \mathrm{C}}=13.9677+0.3797 \mathrm{x}-0.0473 \mathrm{x}^{2}+$ $0.0016 \mathrm{x}^{3} \mathrm{R}^{2}=0.7589 \mathrm{Y}_{16 \mathrm{C}}=3.3732-0,1223 \mathrm{x}+0.0090 \mathrm{x}^{2}$ $\mathrm{R}^{2}=0.9307$.

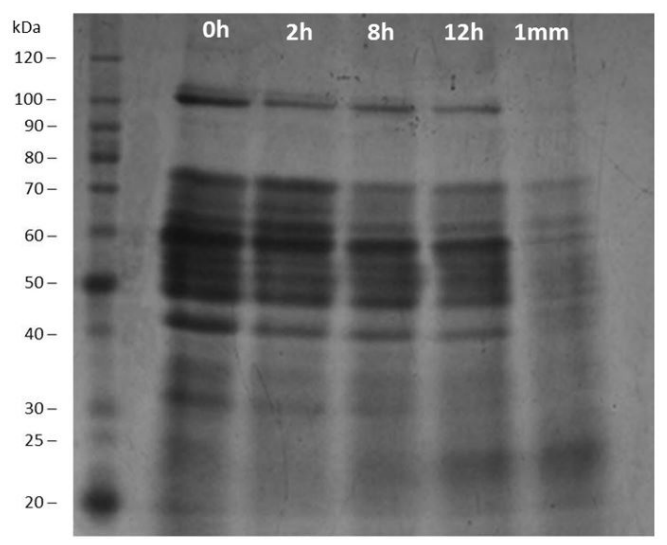

Figure 4. Electrophoretic pattern of heat-stable proteins in radicles of Anadenanthera colubrina seeds during germination. All groups of heat-stable proteins presented less intense bands in germinated seeds ( $1 \mathrm{~mm}$ radicle).

which were gradually reducing until the end of germination. Germinated seeds with $1 \mathrm{~mm}$ radicle showed a much lower heat-resistant protein content when compared to dry seeds (0 hours of imbibition).

\subsection{Ultrastructural analysis}

Figure 5A presented the scanning electronic microscopy image of seed imbibed for 2 hours where the radicle meristem cells were uniforms, and the plasmalemma was intact and adhered to the cell wall.

The hydration by $2 \mathrm{~h}$ followed by dehydration resulted in an irregular aspect of the cell walls, which appears to be the physic effect of dehydration. (Figure 5B). Figure 5C, D presented germinated seeds with $1 \mathrm{~mm}$ radicle before and after dehydration respectively. The dehydration of germinated seeds resulted in great disruption culminating in cell collapse. Due to intense loss of water, the plasmalemma detached from the cell wall.

\section{Discussion}

\subsection{Imbibition curve and imbibition and desiccation tolerance loss}

A. colubrina seeds presented fast germination (nearly 18 hours) and the absence of stage II might be view as an adaptive strategy in colonizing environments. Some authors, as Parsons (2012) report that fast germination species (until $24 \mathrm{~h}$ ) present thin and permeable integument, which imbibe water promptly, allowing better utilization of temporarily favorable conditions, as is the case of A. colubrina seeds.

In the present study, it was observed that the loss of desiccation tolerance starts before phase III, and it was fully complete after radicle protrusion. According to studies in cultivated species, the complete loss of desiccation tolerance at the beginning of phase III is well known. However, recent studies have shown that for seeds from forest species the period of loss of desiccation tolerance is variable. Masetto et al. (2014) observed that Sesbania virgata seeds become intolerant to desiccation when protruded radicle reaches $2 \mathrm{~mm}$ while Cedrela fissilis did not tolerate desiccation in any radicle length. In studies with Copaifera langsdorffii seeds, Pereira et al. (2014) verified that desiccation tolerance loss began at the end of the stage I and it was complete by the middle of stage II of germination.

According to the present results and the literature, the mechanisms that provide tolerance to desiccation are gradually disabled during the germination process, and the radicle protrusion is the mark of desiccation tolerance loss in many species. In this work, it was also observed that the total loss of desiccation tolerance occurs after the root protrusion, but it is possible to observe an accentuated reduction in the percentage of formation of normal seedlings (only 20\%), before germination, with approximately 12 hours of imbibition.

\subsection{DNA Content}

Contrary to expected, radicle cells of $A$. colubrina showed nuclei with DNA duplicate one (4 C), two (8 C) and even three times $(16 \mathrm{C})$ in all evaluated moments (before, during and after germination). This is resulting from repetitive cycles of DNA replication without occurring the cell division, and this process is called endoduplication.

Before germination, most of the species have seeds with $2 \mathrm{C}$ DNA content in the cells and $4 \mathrm{C}$ content at the end of germination, derived from the restart of activity of the cell cycle. In this kind of cell, the proportion of $4 \mathrm{C} / 2 \mathrm{C}$ nuclei in the embryo, during the maturation and germination of the seeds, has been used as vigor mark (Sliwinska, 2009), since 2 C cells (G1 stage) are more resistant to stress and have greater longevity, when compared with $4 \mathrm{C}$ cells (G2 stage). Besides, the state change from desiccation tolerant to sensitive in orthodox seeds coincides with the 

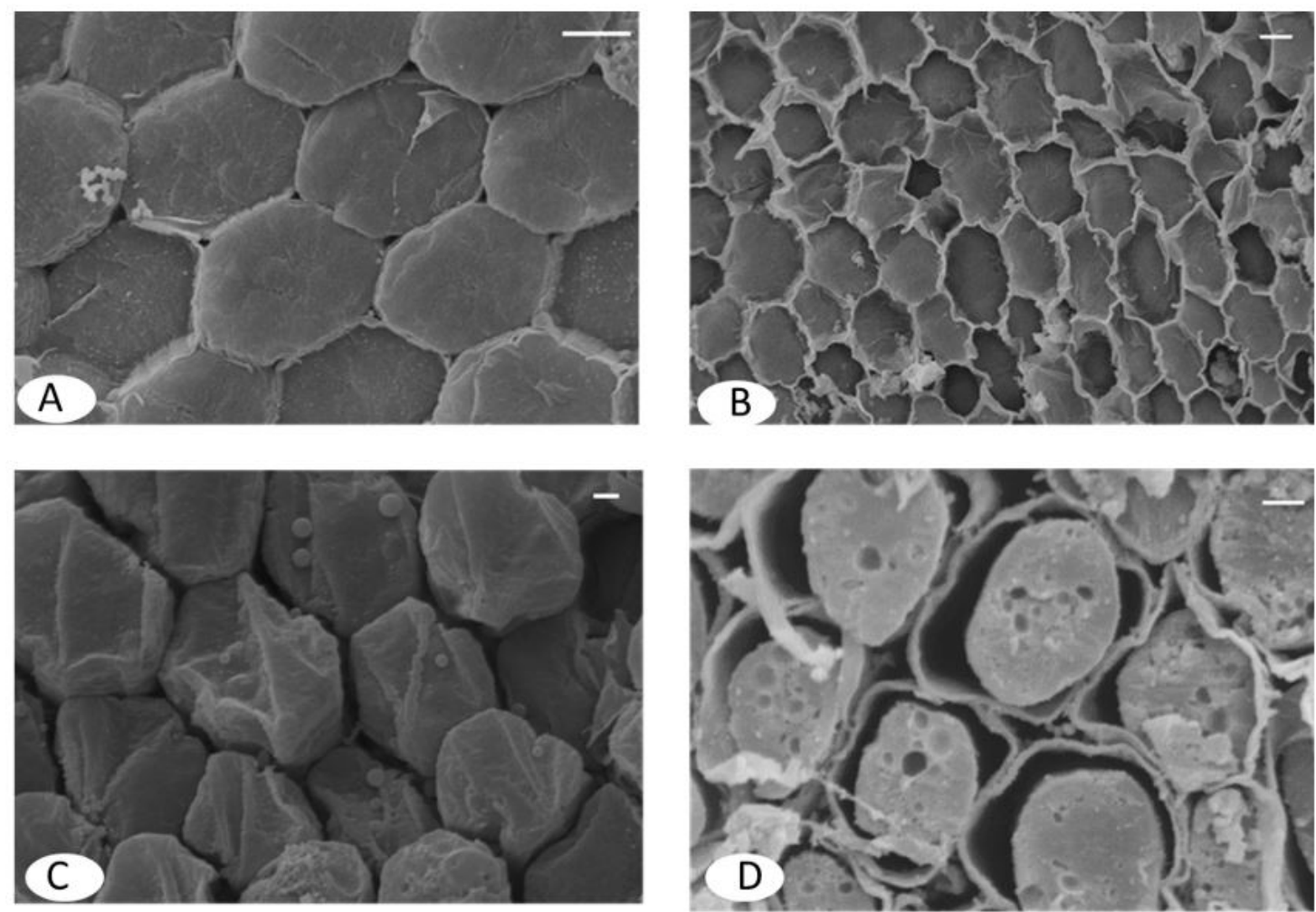

Figure 5. Scanning electron micrographs of radicle cells of Anadenanthera colubrina embryo axis. Note: (A) after 2 hours of imbibition; (B) after 2 hours of imbibition and later dehydration; (C) germinated seeds (radicles 1mm length); (D) germinated seeds (radicles $1 \mathrm{~mm}$ length) and dehydrated. Bars: $(\mathrm{A}-\mathrm{C})=10 \mu \mathrm{m} ;(\mathrm{D})=2 \mu \mathrm{m}$.

cells entrance in the G2 stage, which may be one of the causes of desiccation sensibility (Boubriak et al., 1997). For polysomatic species, the use of another marker to establish the physiological state in relation to desiccation tolerance is necessary.

There are many hypotheses about the purposes of endoduplication in seeds, and one explanation is that the increase of DNA content might be useful to supply the great demand for proteins during the embryogenesis (Lee et al., 2009). In addition, the increase in the number of DNA model strands would allow a proportional increase in transcription and translation activities. Another hypothesis says that endoduplication could be a mechanism of nucleotides or nitrogen storage in the embryo since this process is more frequent in the storing tissues of the seeds. Despite these hypotheses, the roles of this mechanism are poorly known (Larkins et al., 2001).

In conclusion, Anadenanthera colubrina seeds germinate in few hours, thus, the presence of more DNA strands could be an adaptive advantage that enables fast availability of molecules required for germination, such as proteins and enzymes.

\subsection{Heat-stable proteins}

The gradual reduction of heat resistant proteins during germination, along with the loss of desiccation tolerance in Anadenanthera colubrina seeds is according to reported in the literature. The importance of the heat-resistant proteins in desiccation tolerance is related to their hydrophilic nature, acting as hydration buffer together with reducing sugars, they contribute to the formation of the vitreous state, in which the ion mobility of free radicals is greatly reduced, preventing oxidation reactions. Besides, these proteins have been associated with renaturation of proteins, acting as chaperones (Battaglia et al., 2008).

Studying pea seeds, Wang et al. (2012) evaluating changes in proteome during germination, observed that groups of LEA protein progressively reduced after $18 \mathrm{~h}$ of imbibition, and the reduction was coincident with the loss of desiccation tolerance. Wang et al. (2012) also observed that groups of seeds resistant to desiccation presented higher accumulation of heat-stable proteins. According to Huang et al. (2012), desiccation tolerance loss in maize seeds is also associated with a reduction in the content of hydrophilic proteins during germination. In a study with sunflowers, Personat et al. (2014) verified that the simultaneous overexpression of two genes that transcribes heat-stable protein, increased the tolerance to desiccation, reaching to drastic levels of dehydration.

The HSP may be organized in six distinct classes, according to their molecular weights: HSP 100, HSP 90, HSP 70, HSP 60, low molecular weight proteins (17-30 KDa), and ubiquitin (8.5 KDa) (Waters et al., 1996). High molecular weight proteins present great similarity in its 
sequences, however, their functions and cellular location are very different (Vierling, 1991). Proteins from PRC100 family act protecting denaturation and protein aggregation (Wang et al., 2004). The main role of PRC70 is related to stress conditions and they are found in the cytoplasm, mitochondria, nucleus, endoplasmic reticulum and chloroplasts. The overexpression of this protein group leads to environmental stress tolerance (Wang et al., 2004). The PRC60 class helps on folding and assembly of protein subunits.

\subsection{Ultrastructure characteristics}

Contrary to what occurs in late developing seeds, the loss of water after the germination is lethal for embryo cells of orthodox seeds. In this work, it was possible to observe the occurrence of membrane detachment (Figure 5D), which actually represents the separation between the membrane from the cell wall. Such response is common in recalcitrant seeds, either before or after the onset of germination (Berjak and Pammenter, 2000). In studies with newly dispersed recalcitrant seeds of Trichilia emetica, Kioko et al. (2006) found cells with big vacuoles, polysomes, and several organelles well developed and distributed along the cytoplasm. After severe drying, the ultrastructure of these cells was completely disturbed, hindering organelle identification. The membrane shift accompanied by cell death have been broadly reported in the literature. Pereira et al. (2014) also observed cell collapse and plasmatic membrane shift in Copaifera langsdorffii seeds imbibed by 144 hours e dehydrated.

An advantage of the desiccation tolerating tissues is the flexibility maintenance of the cellular wall during dehydration. Drying process cause fewer injuries at the beginning of germination than at the end of germination (Figure 5B-D). In resurrection plants, for example, the cellular wall bending and the cells contraction allow the reversibility of withering and curling of the leaves (Moore et al., 2006; Moore et al., 2008). In orthodox seeds, the correct bending of the association between the plasmatic membrane and cellular wall at the end of the seed maturing process is essential to prevent mechanic damages to tissues (Vicré et al., 2004).

The cell "bending" is related to the chemical composition of cellular membranes. Orthodox seeds present a high proportion of galactans and polysaccharides with arabinose, which acts as a plasticizer, increasing the cell wall flexibility and decreasing strong interactions between polysaccharides (Jones and McQueen-Mason, 2004; Moore et al., 2008). In some orthodox sees, the arabinose proportion is extremely high, ranging from $38 \%$ to $60 \%$ of the cellular walls (Shiga and Lajolo, 2006). On the other hand, recalcitrant seeds, as Inga vera, the arabinose proportion is very reduced to approximately $20 \%$. In the present work, the sugar content variation along the imbibition was not studied, but we observed that the loss of desiccation tolerance is associated with the reduction of other protective mechanisms such as heat-resistant proteins.
In summary, we observed in the present work that the loss of desiccation tolerance in Anadenanthera colubrina seeds begins at the first hours of imbibition and it is complete after radicle protrusion. The loss of desiccation tolerance is characterized by ultrastructural disorganization and it is coincident with the reduction of protection mechanisms, such as heat-resistant proteins and it is not related to DNA content variation.

\section{Acknowledgements}

We thank CAPES for the scholarship concession, the Electronic Microscopy Lab, and the Cytogenetics Lab at UFLA for the collaboration. The Authors are also grateful to $\mathrm{CNPq}$ and Fapemig for the financial support.

\section{References}

ALPERT, P., 2006. Constraints of tolerance: why are desiccationtolerant organisms so small or rare? The Journal of Experimental Biology, vol. 209, no. 9, pp. 1575-1584. PMid:16621938. http:// dx.doi.org/10.1242/jeb.02179.

ALVES, E., 2004. Apostila do curso introdutório à microscopia eletrônica de varredura. Lavras: Editora UFLA. 43 p.

BATTAGLIA, M., OLVERA-CARRILLO, Y., GARCIARRUBIO, A., CAMPOS, F. and COVARRUBIAS, A.A., 2008. The enigmatic LEA proteins and other hydrophilins. Plant Physiology, vol. 148, no. 1, pp. 6-24. PMid:18772351. http://dx.doi.org/10.1104/ pp.108.120725.

BERJAK, P. and PAMMENTER, N., 2000 [viewed 11 January 2016]. What ultrastructure has told us about recalcitrante seeds. Revista Brasileira de Fisiologia Vegetal, vol. 12, no. spe., pp. 22-55. Available from: http://www.cnpdia.embrapa.br/rbfv/pdfs/ v12Especialp22.pdf

BERJAK, P. and PAMMENTER, N.W, 2008. From Avicennia to Zizania: seed recalcitrance in perspective. Annals of Botany, vol. 101, no. 2, pp. 213-228. http://dx.doi.org/10.1093/aob/mcm168.

BEWLEY, J.D. and BLACK, M., 1994. Seeds: physiology of development and germination. New York: Plenum Press.

BLACKMAN, S.A., WETTLAUFER, S.H., OBENDORF, R. and LEOPOLD, C., 1991. Maturation proteins associated with desiccation tolerance in soybean. Plant Physiology, vol. 96, no. 3, pp. 868-874. PMid:16668267. http://dx.doi.org/10.1104/ pp.96.3.868.

BOUBRIAK, I., KARGIOLAKI, H., LYNE, L.O.D., 1997. The requirement for DNA repair in desiccation tolerance of germinating embryos. Seed Science Research, vol. 7, no. 2, pp. 97-105. http:// dx.doi.org/10.1017/S0960258500003433.

CARVALHO, P.E.R., 1994. Espécies florestais Brasileiras: recomendações silviculturais, potencialidades e uso da madeira. Brasília: Embrapa Produção de Informação. 640 p.

DICKIE, J.B. and PRITCHARD, H.W., 2002. Systematic and evolutionary aspects of desiccation tolerance in seeds. In: M. BLACK and H.W. PRITCHARD, eds. Desiccation and survival in plants: drying without dying. Wallingford: CAB International, pp. 239-259.

FARIA, J.M., BUITINK, J., VAN LAMMEREN, A.A. and HILHORST, H.W., 2005. Changes in DNA and microtubules 
during loss and re-establishment of desiccation tolerance in germinating Medicago truncatula seeds. Journal of Experimental Botany, vol. 56, no. 418, pp. 2119-2130. PMid:15967778. http:// dx.doi.org/10.1093/jxb/eri210.

HAND, S.C., MENZE, M.A., TONER, M., BOSWELL, L. and MOORE, D., 2011. LEA proteins during water stress: not just for plants anymore. Annual Review of Physiology, vol. 73, no. spe., pp. 115-134. http://dx.doi.org/10.1146/annurev-physiol-012110-142203.

HUANG, H., MØLLER, I.M. and SONG, S.Q., 2012. Proteomics of desiccation tolerance during development and germination of maize embryos. Journal of Proteomics, vol. 75, no. 4, pp. 1247-1262. PMid:22108046. http://dx.doi.org/10.1016/j.jprot.2011.10.036.

JONES, L. and MCQUEEN-MASON, S., 2004. A role for expansins in dehydration and rehydration of the resurrection plant Craterostigma plantagineum. FEBS Letters, vol. 559, no. 1-3, pp. 61-65. PMid:14960308. http://dx.doi.org/10.1016/ S0014-5793(04)00023-7.

KIOKO, J.I., BERJAK, P. and PAMMENTER, N.W., 2006. Viability and ultrastructural responses of seeds and embryonic axes of Trichilia emetica to different dehydration and storage conditions. South African Journal of Botany, vol. 72, no. 1, pp. 167-176. http://dx.doi.org/10.1016/j.sajb.2005.07.001.

LARKINS, B.A., DILKES, B.P., DANTE, R.A., COELHO, C.M., WOO, Y.M. and LIU, Y., 2001. Investigating the hows and whys of DNA endoreduplication. Journal of Experimental Botany, vol. 52, no. 355, pp. 183-192. PMid:11283162. http:// dx.doi.org/10.1093/jexbot/52.355.183.

LEE, H.O., DAVIDSON, J.M. and DURONIO, R.J., 2009. Endoreplication : polyploidy with purpose. Genes \& Development, vol. 23, no. 21, pp. 2461-2477. PMid:19884253. http://dx.doi. org/10.1101/gad.1829209.

LORENZI, H., 2000. Árvores Brasileiras: manual de identificação e cultivo de plantas arbóreas do Brasil. Nova Odessa: Instituto Plantarum. $194 \mathrm{p}$.

MASETTO, T.E., FARIA, J.M. and FRAIZ, A.C., 2014. Reinduction of desiccation tolerance after germination of Cedrela fissilis Vell. seeds. Annals of the Brazilian Academy of Sciences, vol. 86, no. 3, pp. 1273-1285. PMid:25140505. http://dx.doi. org/10.1590/0001-3765201420130164.

MOORE, J.P., FARRANT, J.M. and DRIOUICH, A., 2008. A role for pectin-associated arabinans in maintaining the flexibility of the plant cell wall during water deficit stress. Plant Signaling \& Behavior, vol. 3, no. 2, pp. 102-104. PMid:19704722. http:// dx.doi.org/10.4161/psb.3.2.4959.

MOORE, J.P., NGUEMA-ONA, E., CHEVALIER, L., LINDSEY, G.G., BRANDT, W.F., LEROUGE, P., FARRANT, J.M. and DRIOUICH, A., 2006. Response of the leaf cell wall to desiccation in the resurrection plant Myrothamnus flabellifolius. Plant Physiology, vol. 141, no. 2, pp. 651-662. PMid:16603665. http:// dx.doi.org/10.1104/pp.106.077701.

PARSONS, R.F., 2012. Incidence and ecology of very fast germination. Seed Science Research, vol. 22, no. 3, pp. 161-167. http://dx.doi.org/10.1017/S0960258512000037.
PEREIRA, W.V.S., FARIA, J.M.R., TONETTI, O.A. and SILVA, E.A., 2014. Loss of desiccation tolerance in Copaifera langsdorffii Desf. seeds during germination. Brazilian Journal of Biology = Revista Brasileira de Biologia, vol. 74, no. 2, pp. 501-508. PMid:25166338. http://dx.doi.org/10.1590/1519-6984.19712.

PERSONAT, J.-M., TEJEDOR-CANO, J., PRIETO-DAPENA, P., ALMOGUERA, C. and JORDANO, J., 2014. Co-overexpression of two Heat Shock Factors results in enhanced seed longevity and in synergistic effects on seedling tolerance to severe dehydration and oxidative stress. BMC Plant Biology, vol. 14, no. 1, pp. 56. PMid:24593798. http://dx.doi.org/10.1186/1471-2229-14-56.

SHIGA, T.M. and LAJOLO, F.M., 2006. Cell wall polysaccharides of common beans (Phaseolus vulgaris L.): composition and structure. Carbohydrate Polymers, vol. 63, no. 1, pp. 1-12. http:// dx.doi.org/10.1016/j.carbpol.2005.06.025.

SLIWINSKA, E., 2009. Nuclear DNA replication and seed quality. Seed Science Research, vol. 19, no. 1, pp. 15. http:// dx.doi.org/10.1017/S0960258508186275.

SUN, W.Q., 1999. State and phase transition behaviors of Quercus rubra seed axes and cotyledonary tissues: relevance to the desiccation sensitivity and cryopreservation of recalcitrant seeds. Cryobiology, vol. 38, no. 4, pp. 372-385. PMid:10413579. http://dx.doi.org/10.1006/cryo.1999.2180.

VÁZQUEZ-RAMOS, J.M. and SÁNCHEZ, M.D.L.P., 2003. The cell cycle and seed germination. Seed Science Research, Wallingford, vol. 13, no. 2, pp. 113-130. http://dx.doi.org/10.1079/ SSR2003130.

VICRÉ, M., FARRANT, J.M. and DRIOUICH, A., 2004. Insights into the cellular mechanisms of desiccation tolerance among angiosperm resurrection plant species. Plant, Cell \& Environment, vol. 27, no. 11, pp. 1365-3040. http://dx.doi.org/10.1111/j.13653040.2004.01212.x.

VIERLING, E., 1991. The roles of heat shock proteins in plants annual reviews: plant physiology. Plant Molecular Biology, vol. 42, no. 1, pp. 579-620. http://dx.doi.org/10.1146/annurev. pp.42.060191.003051.

WANG, W., VINOCUR, B., SHOSEYOV, O. and ALTMAN, A., 2004. Role of plant heat shock proteins and molecular chaperons in the abiotic stress response. Trends in Plant Science, vol. 9, no. 5, pp. 1360-1385. PMid:15130550. http://dx.doi.org/10.1016/j. tplants.2004.03.006

WANG, W.Q., MØLLER, I.M. and SONG, S.Q., 2012. Proteomic analysis of embryonic axis of Pisum sativum seeds during germination and identification of proteins associated with loss of desiccation tolerance. Journal of Proteomics, vol. 77, pp. 68-86. PMid:22796356. http://dx.doi.org/10.1016/j.jprot.2012.07.005.

WATERS, E.R., LEE, G.J. and VIERLING, E., 1996. Evolution, structure and function of the small heat shock proteins in plants. Journal of Experimental Botany, vol. 47, no. 296, pp. 325-338. http://dx.doi.org/10.1093/jxb/47.3.325 